\title{
A Study on the Application of Functional Equivalence to Business English E-C Translation
}

\author{
Lifen Gao \\ School of Foreign Languages, Yangtze University, Jingzhou, Hubei, China
}

\begin{abstract}
The "functional equivalence" advanced by the famous American translation theorist, Eugene Nida has been widely used by various translators and has had a profound impact on China's translation field. The application of functional equivalence theory to business English E-C(English-to-Chinese) translation is of great significance to the future translation of business English. Based on that, this thesis studies how the functional equivalence theory is applied to business English E-C translation from the view of equivalence of semantic message, equivalence of stylistic message and equivalence of cultural message with the practice of E-C translation effectively in order to ensure the accessibility and efficient communication of international business activities.
\end{abstract}

Index Terms — functional equivalence, business English, business English translation

\section{INTRODUCTION}

With the further development of China's economy and the globalization of the world economy, the economic exchange trades between countries are becoming increasingly close. In order to make the process of economic trade more convenient and professional, business English translation has become the focus of the study of scholars.

Business English which functions as a language tool for serving business activities among the countries all over the world is different from general English from the aspect of lexical, stylistic and textual features. Hence, general translation theory may be not entirely applicable to business English translation. First of all, business English involves a wide range of foreign trade translation, and almost covers every aspect of our society and other fields. In addition, the translation of business English is very special in time and efficiency, which is determined by the changing economic situation at home and abroad. We cannot, as for other types of translations, take weeks or even years to think about how to translate well, but have to convey information as quickly as possible. How to determine your business English translation strategies is a matter of both theoretical and practical significance. On account to these characteristics, the principles and theories should be applicable in the process of translation. Even though many scholars have made a lot of research on translation, but unfortunately a systematic theory was not achieved. With continuous research, Eugene Nida, konwn as the translation theorist, advanced the "functional equivalence" theory which is called dynamic equivalence in the past. This theory has had a profound impact on China's translation field, and many translators make full use of this theory in the translation of business English.

This thesis begins with the illustration of Nida's functional equivalence theory which focuses on the definition of functional equivalence and its three features, namely, equivalent, natural and the closest. And then the author compares Business English as a kind of English for specific purpose with English for general purpose, finding that the difference between them lies in the unique linguistic features. Therefore, this thesis introduces the linguistic features of business English from the perspective of lexical level, syntactic level and textual level after the discussion about the definition of business English. At the same time, the thesis demonstrates the four criteria with which the business English translation process should comply---faithfulness, fluency, exactness and consistency. Based on this, the fourth part studies the application of functional equivalence theory applied to business English E-C translation from the view of equivalence of semantic message, equivalence of stylistic message and equivalence of cultural message. Finally, this thesis summarizes the main ideas of the thesis and the limitation of the thesis.

\section{NIDA's FUNCTIONAL EQUIVALENCE THEORY}

\section{A. The Definition of Functional Equivalence}

Nida has a view that equivalence includes two types, formal equivalence and dynamic equivalence. Nida gives a definition for "formal equivalence which focuses on the form and content of the message itself. However, the dynamic equivalence focuses on the principle of equivalence effect." (Nida, 1964, p. 197)

"Dynamic equivalence is to be defined in terms of the degree to which the receptors of the message in the receptor language respond to it in substantially the same manner as the receptor in the source language." (Nida, 1969, p. 24) 
In order to emphasize the concept of "functional"and avoid the misunderstanding of "dynamic" that some persons regarded the term "dynamic" as referring only to something which has impact, he used "functional equivalence" instead of "dynamic equivalence". He explains that the functional equivalence is more likely to offer a much more reasonable basis for translation "as a form of communication with a focus on what translation does or perform." (Nida, 1993, p.124)

Nida clarifies the goal of dynamic equivalence is to seek "the closest natural equivalent to the source language message." (Nida, 1969, p.12) That is to say Nida's theory focuses on the functional equivalence rather than formal equivalence.

Later on, functional equivalent theory is split into two levels--that is the minimal level and the maximal level. From the minimal level, the functional equivalence is "The readers of a translated text should be able to understand it to the extent that they can image how the original readers understand and appreciated it." (Nida, 2001, p.136) Any translation which is less than the minimal level of equivalence is hardly to be accepted. From the perspective of maximal level, the definition of functional equivalence can be regarded as " The readers of a translated text should be understand and appreciate it in substantially the same manner as the original readers did." The maximal level stands for a high degree of language-culture correspondence between target language and source language. The target language readers can have a response that is very close to that of original readers.

\section{B. The Features of Functional Equivalence}

In Toward a Science of Translating, Nida firstly states the principle of dynamic equivalence, which he defines as "the relationship between receptor and message should be substantially the same as that which existed between the original receptors and the message." (Nida, 1964, p. 159) He also says that the goal of the functional equivalence theory is to make the translation achieve the closest natural equivalent to the source-language message. Nida further puts forward the essential features of functional equivalence are made up of the following three essential terms aiming at the receptor response is similar to the original writer meaning at highest degree.

(i) "Equivalent, which points toward the source-language message;

(ii) Natural, which points toward the target language;

(iii) Closest, which binds the two orientations together on the basis of the highest degree of approximation."(Nida, 1964, p. 166)

The meaning of equivalent is to "reproduce the message of the original text as the equivalence of the response rather than the form." (Zhao Yong, 2013, p. 85) which is the most primary part of the translation process. Only when the translator achieve this goal, will the receptor language conveys the primary message of the source language.

Apart from knowing the features, the following adaptation should be applied in the E-C translation of business English.

(i) "The greater the differences in the source and target cultures, the greater the need for adjustments.

(ii) The greater the differences between the source and target languages, the greater the need for adjustments.

(iii) The more distinctive the style of the source text, the greater the number of adjustments.

(iv) The greater the differences in social and educational levels of the source and target audiences, the greater the number of adjustments.

(v) "The more a translated text is dependent on an accompanying code, the greater the number and variety of adjustments." (Nida, 1997, p.125)

All in all, as the introduction about Nida's functional equivalence mentioned above, it is essential to the translation field. In translation, the translator should not only pay attention to the semantic message and stylistic message but also the cultural message which is more important to achieve the functional equivalence.

\section{AN INTRODUCTION OF Business ENGLISH AND THE CRITERIA OF BUSINESS ENGLISH TRANSLATION}

"Business English, as a language tool for the communication of international economic exchanges and business activities, stands out as a new, interdisciplinary and comprehensive discipline, which exists in the whole process of business activities." (Duan Yunli, 2013, p. 1) Business English, in terms of the essence of the language, is a complex of English vocabulary and sentence pattern and literary form which are often used in commercial field reflecting the professional affairs in the field.

\section{A. The Linguistic Features of Business English}

\section{(1) The Lexical Features of Business English}

The lexical features of business English mainly consists of the following four aspects.

(i) Using formal vocabulary. Business English has a preference for formal vocabulary because of the binding and normative characters of business documents.

(ii) Using single word. Single here means the meaning of the word is comparatively single. Unlike English for general purpose, business English take the words which has relatively single meaning instead of those words of rich and flexible meaning in order to grant the accuracy and preciseness of the text. 
(iii) Using terminologies. Business English is a discipline which is equipped with highly applicability and comprehensiveness, involving international trade, marketing, finance, law, insurance, logistics, advertising and other fields. As a result from such wide fields, business English has a large number of terminologies.

(iv) Using abbreviations, foreign words and archaic words. Newmark (1988) points out in the classification of the English word meaning theory that terminologies,archaic words and foreign words are suitable for the accurate and concise requirements of business English texts.

(2) The Syntactic Features of Business English

(i) Using passive sentences. Passive voice is one of the language features of business English which makes language structure rigorous, the semantics accurate and expression tight, strengthens the logic and transfers the stressed object to improve the objectivity, fairness and embody the principle of good manners.

(ii) Using complex sentence. The use of complex sentence in business English makes the context clearer and more accurate,makes the manner of writing more rigorous and refined.

(iii) Using the sentence containing "shall". In business English, the sentence containing "shall" is often used with the purpose of enhancing the mood. Especially in the business contract, "shall"is not only used to embody future tense,but also indicate the responsibilities and obligations of both parties.

(iv) Using established formats. So-called established formats are some sentence patterns which are often used. Some established formats will be introduced as follows:

(3) The Textual Features of Business English

(i) Accurate and concrete. In business English,the expression of sentences must be specific and accurate, otherwise, inconvenience even loss of the company will be aroused.We can compare the following two groups of sentences.

(ii) Concise style of writing. Concise and comprehensive is one of the characteristics of business English. In business field, time is money. The concise style of writing can save the time. The expression of business English is more concise than that of other type of literature.

(iii) Normalized structure. Business English differs from English for general purposes in terms of a certain relevance. Therefore, the format of business English must be normative. Taking the business correspondence for example. Business correspondence includes inside name and address, date, salutation, body, complementary closing, signature. Different types of business documents have different formats.

(iv) Euphemistic expression.

a. Objective expression. In business English, there is a preference to using objective expression which is easier to be accepted because of the more appropriate style of writing.

b. Euphemistic rejection. In business activities, the occasion often emerges where the requirements put forward by the opposite are unreasonable and unacceptable. Then,adopting the straight way to refuse the requirements will lead to the failure of the business activities. Therefore,making use of euphemistic rejection achieves the goal of refusing also Scruples the opposite's mind.

\section{B. The Criteria of Business English Translation}

(i) Faithfulness. "So-called faithfulness is to be faithful to the original content." (Wen Jingjing, 2014, p.191) The translator must convey the original content completely without any manipulation. Business English translation must be faithful to the original text, achieving the equivalence of information rather than similarities. There is a point to note is that the faithfulness does not mean being faithful to the language expression form but faithful to the content will and style effect of the original text.

(ii) Fluency. "Fluency means translation in line with the language of the premise, can be easy to understand." (ibid, p. 192) In other words, in the process of translating one language into another language, translation should be smooth, clear and easy to be understood. The translation must be a clear modern language, fluent statement, rigorous structure.

(iii) Exactness. Exactness is the most important part in business English translation. "Exactness refers to the translation should understand and select the words correctly, express the concept accurately, express the the original language information completely via translation language." (Duan Yunli, 2013, p.13)

(iv) Consistency. The so-called consistency is in the process of business English translation, concepts, terminology, etc. should be maintained unity at any time and does the same concept or the term should not be transformed randomly, such as “exclusive”, exclusive territory is“独占区域”, however, exclusive contract means “转销合同”.

\section{Application of Functional Equivalence to Business English E-C Translation}

Since Nida put forward the functional equivalence, the theory has been widely used in business English E-C translation. This part will analyze how the functional equivalence is applied to business English E-C translation.

A. Equivalence of Semantic Message of Target Language and Source Language in Business English E-C Translation 
Semantic message is the foundation of stylistic message and cultural message as the stylistic and cultural message must be expressed through the basic meaning of language. Semantic message consists of surface structure semantic message and deep structure semantic message.

1 Equivalence of Surface Semantic Message of Target Language and Source Language

Surface semantic message refers to the literal meaning of discourse. Examples will be cited to prove the equivalence of surface semantic message of source language and target language.

1a. APEC Business Travel Card (ABTC): Eligibility

A business person living in the Hongkong Special Administrative Region can apply for an ABTC if he/she:

(i) has a HongKong permanent identity card;

(ii) has not previously been denied entry to any of the participating economies;

(iii) has never been convicted of a criminal offence;

1b.亚太经合组织商务旅游证: 申请资格

若符合以下条件，在香港特别行政区定居的经商人士可以申请亚太经合组织商务旅游证:

(i) 持有香港永久性居民身份证;

(ii) 曾未遭遇任何参与此计划的地区拒绝入境;

(iii) 从没有因触犯任何刑事罪行而被判罪;

This translation mentioned above is the translation of legal documents,one type of business English texts. All legal documents just express the literal meaning without any extension. The legal documents clearly clarify the eligibility for the ABTC. Therefore, the legal language carries the message that is conveyed by the surface of the language, and there is no deep semantic structure.

Apart from the translation of business English legal document applies to the surface semantic message, the translation of business English contract should be in accordance with the surface semantic message. For example,

2a.The Contractor shall be responsible for the accurate delivery of the original parameters of the relevant points, lines and levels in accordance with the Engineer's work and shall, as aforesaid, be responsible for calibrating the orientation, level, size and alignment of the various parts of the Works and shall take responsible for providing everything that are related equipment, equipment and labor.

2b. 承包商应负责根据工程师的工作准确交付相关点、线和水平的原始参数, 并应按上述规定校准各部分的方 向、水平、尺寸和对齐方式工程。负责提供一切必要的相关设备，设备和人力。

This business English contract stipulates the Contractor's obligation clearly. Contract is the legal evidence in business activities which stipulates the rights and obligations of trade parties. Therefore, when translating business English contract, no extension shall be added, just in accordance with the surface semantic message.

\section{Equivalence of Deep Structure Semantic Message of Target Language and Source Language}

Deep structure semantic information refers to the meaning implied by the surface structure of the language. This kind of meaning is to be understood through the understanding and speculation of the context. In order to understand the deep structure semantic message, the translator must make use of his knowledge of society, history, culture and other aspects of the source language. Examples will be listed to prove the equivalence of deep structure semantic message.

3a.The Unique Spirit of Canada.

3b. 别具风味的加拿大酒, 独特的加拿大精神。(酒类广告)

In this Canadian wine advertising, if the translator just understand the surface structure semantic message, the advertisement is only conveyed the taste of wine. However,the word "spirit" is the highlight of the advertisement. It has “精神” and “烈酒、醇酒” double meaning. The source language makes use of the semantic pun of "spirit” to embody the wine and spirit in Canada are both unique. The equivalence of deep structure semantic message let the receptors have a deep understanding of the advertisement.

4a. Whatever path you take in life, you'll face financial challenges and opportunities along the way. With the Principle Financial Group, you'll have all the tools to handle them. All of our financial products and services for business or individuals, has their own unique advantage built in. That's the Principle Edge. Financial products that offer you an edge. The Principle Financial Group.

4b. 无论您在生活中采取何种路径, 您一路上都将面临经济挑战和机遇。选择汇富财团, 您将拥您需要用来应 对这些经济挑战的所有工具。我们的每一个金融产品和服务, 无论是服务于商业还是个人, 都有自己内在的独 特的优势，这就是资本优势。金融产品给你一个转折点。汇富财团。

The advertisement mentioned above is with the picture of corresponding knife. Without careful attention, people will regard it as an advertisement of knife. The most important of the ad is the "edge" which is not only has the meaning of “刀 刃、刀锋”, but also has the meaning “事情的转折点、作用、优势”. “Edge”in the first sentence of the ad means “优 势、作用”. However, in the last sentence but one, “edge” means “事情的转折点”. Apart from this, the “principle” is also a pun. When translating the English words in company name into Chinese, it is usually adopted transliteration. However ,the word has the basic meaning “主要的” and “资本”. Seeing the company “the Principle Financial Group , 
the name reminds the English readers of consortium which is well-capitalized. In order to make the target language readers have the same association, the company name is translated into “汇富财团”.

\section{B. Equivalence of Stylistic Message of Target Language and Source Language in Business English E-C Translation}

"Style" actually refers to different literary forms. Stylistic message is one of the message that is passed by language which is regarded as a message carrier. The transmission of stylistic message can not be ignored in the translation, otherwise the translation not only loses a lot of information but also the translation is not appropriate. The equivalence of stylistic message of target language and source language indicates the translation is intended to reproduce the original tone. For example

(i) Business correspondence

5a.Offer of a Quality Product--Bamboo Carvings

Dear Sirs/Madams,

We are very delighted to send you this letter with a copy of our catalogue for bamboo carvings. The high quality of our product is well-known and we are confident that a trail order would convince you our goods are excellent.

We are offering you goods of the highest quality on unusually generous terms and would welcome the opportunity to serve you.

Yours faithfully

The Brunner Trade Company

$5 b$. 推销优质产品——竹雕

先生/女士台鉴:

现随信寄上竹雕目录表一份, 请查收。我们的产品以优质著称。贵方如果试定一次货物, 会确信我们的货物 是一流的。

我们以最合理的价格提供最高档的产品, 希望有机会为贵方服务。

您最忠实的

布鲁洛贸易公司

The example mentioned above is the translation of business English correspondence. The translation must reflect the format and language features of business English correspondence.

(ii) Legal Documents

6a.Insurance policies or certificate in duplicate in blank of $110 \%$ of invoice value covering all risks and war risks as per CIC of the People's Insurance Company of China dated $1^{\text {st }}$ January 1981 with claims payable at...in the currency of draft (irrespective of percentage), including 60 days after discharge of the goods at port of destination subject to CIC.

6b.保单或保险凭证一式两份，空白背书，按发票金额的110\%投保中国保险公司1981年1月1日实施保险条款 的综合险和战争险, 按汇票使用的货币在.....赔付（不计免赔），并按照中国保险条款，保险期限在目的港卸船 后60天为止。

The above example is a legally binding clause. The translation should be equipped with the characteristics of legal documents. If unfamiliar with the legal language, the translator is hard to select a proper word to translate "endorsed in blank”. It is a terminology which means “空白背书”.

(iii) Advertisement

7a.Apple thinks different.

7b. 苹果电脑, 不同凡“想”。

The source language advertisement originally means Apple adopts thinking mode different from others. The translation keep the "thinks" which makes the product is more outstanding. The translation meets the features of advertisement.

(iv) Telephone note

8a.Telephone Note

Date: 20/9/2009

Message for: Peter Johnson

Message: Alice Black called from the United States. Please call her today before 5 p.m. Or any time tomorrow on 512-442-XXXXre the pricing of new products.

Taken by: John Brown

8b. 电话留言

日期: 2009/9/20

收信人名字: 彼得. 约翰逊

正文: 爱利斯. 布莱克从美国来电。请今天下午五点前或者明天就新产品定价一事回电, 电话号码: 512-422-XXXX。

This is a translation of telephone note. The translation complies with the format of the source language. In addition , the translation is consistent with the conciseness and politeness of the source language. 


\section{Equivalence of Cultural Message of Target Language and Source Language in Business English E-C Translation}

\section{(1) Equivalence of Environmental Culture in Business English E-C Translation}

Environmental culture refers to the culture formed by the natural environment and social environment of the region appearing in different ethnics take different languages to express toward one phenomenon or thing. The specific growth environment allows people to develop a specific mindset, so in the process of business English E-C translation, the translator may face some difficulties. "In summer keep exercising during the hottest days; in winter do the same thing during the coldest weather” can be translated into the Chinese proverb “夏练三伏，冬练三九”. This means inspiring people to insist on working out.

The United Kingdom is an island. The climate is affected by the North Atlantic warm current, so the weat wind blowing from the ocean is warm and humid. In the British understanding, the west wind is warm. The English word "Zephyr"means the west wind and it is used as the brand name for car. But in Chinese culture, the west wind is cold as "northwest wind" just blows in winter. Usually, it contains a certain derogatory. On the contrary, the east wind is warm, China FAW Group also produces "Dongfeng" brand cars.

Due to the difference of natural environment and social environment, the translator need to translate the source language in accordance with the environment of the target language in the process of business English E-C translation.

\section{(2) Equivalence of Folk Culture in Business English E-C Translation}

Folk culture refers to the culture which is formed from ethnic customs and habits and runs through the daily social life and communication activities customs and habits of the people in daily social life and communication activities. Language comes from life. To some degree, the language expression system is confined by living habit.

(i) Color. In terms of the attitude to color, in western countries, people regard "blue"as meaning of "sad and depressed". They call Monday "blue Monday" because it is the first day to work after the relaxing weekend with a depressed mood. On the contrary, the Chinese see the blue as a meaning of clear and fresh. In the translation of brand, “蓝天” brand is translated into "Blue Sky Lamp". Obviously, it is not in accordance with the folk culture in western countries. In western countries, “red” is connected with blood, violence and danger. In English, red flag means “惹人生气的事”, in which the red means “宁损、负债”. However, Chinese people regard “red” as “happy and festive”. When celebrating the festivals, people are well dress in red to express their happy mood.

(ii) Number. Another obvious example is about the understanding of number.In western countries, number "7" is paid much attention. The brand "7-Up" is translated into “七喜” in Chinese rather than “七上". The number "7" is equal “8”in our country. There are also “Mild Seven”(柔和七星) and “Seven star”(七星).

(3) Equivalence of Religious Culture in Business English E-C Translation

Religious culture refers to the culture formed from religious beliefs, consciousness, etc. which is reflected by cultural difference in taboos. Religious taboos brings various taboos and restrictions for the company when carrying in ternational business activities. The people engaged in business activities should take the religious difference into consideration, otherwise, business communication will be prevented, which will arouse the commercial loss.

In terms of religious culture, some words have the corresponding vocabulary both in English and in Chinese. However, the words should be translated flexibly because of the different religious cultural message. For example, the word “dragon” and “龙”, the surface meaning both means a kind of reptile, but the cultural connotation is different. "Dragon" in English is the symbol of “怪物、恶魔、凶残”. On the contrary, in China, “龙” stands for the dignity and power. “龙” is the symbol of the history of civilization in the past five thousand years. On the basis of the cultural difference, the Chinese with the word “龙” is not translated into “dragon”. “亚洲四小龙” is translated into “four Asian Tigers”.

\section{(4) Equivalence of Historical Culture in Business English E-C Translation}

Historical culture is the culture formed by a specific historical development process and the social heritage of the city store. Different historical origins attribute to different character and lifestyle of all ethnic groups. The history brings people memory and revelation which is reflected by language. Only when the translator master the rich historical and cultural connotation and select the proper translation method, can he convey the intention of the writer appropriately.

It seems that the historical culture has no sense to the translation of business English. On the contrary, business activity is a kind of cross-cultural activity. When the translator have a good knowledge of the historical culture, the translation will be appropriate. The following advertisement indicates the point.

9a.We take no pride in prejudice.(The Times)

$9 b$.正义的力量, 與论的导向。

In the advertisement, "pride in prejudice" is quotes from the famous works Pride and Prejudice written by Jane Austen embodying the "Times" adheres to the principle of fair and impartial. The advertisement has a great impact on the "Times". If the translator is unfamiliar with the cultural background of the source language, he hardly realize the equivalence of cultural message. What's worse, “We take no pride in prejudice” may be translated into “对于你们的误 解, 我们并不骄傲”. In consideration of the target language readers' same response with that of source language readers and the effect of the advertisement, the advertisement can be translated into “正义的力量, 舆论的向导”. 


\section{CONCLUSION}

As business English has its own unique linguistic features from the perspective of lexical level, syntactic level and textual level, the process of business English translation need to comply with the criteria to be in accord with these features, namely, faithfulness, fluency, exactness and consistency. Apart from the equivalence of semantic message and stylistic message of target language and source language, the equivalence of cultural message is also important in the business English E-C translation. Cultural elements play an important role in the process. However, owning to the cultural difference in terms of the environment, folkways, religion and history, the readers of the target language hardy understand and appreciate it as same as the readers of source language do. As we know, the goal of the translation is to seek the closest natural equivalent to the source language which can be regarded as the features of functional equivalence. Based on this, the E-C translation of business English will realize the equivalence of cultural message of target language and source language from the perspectives of environmental culture, folk culture, religious culture and historical culture which will make the readers of target language response with it in the substantially same manner as the readers of source language. In spite of the loss of the meaning in the translation, the translator should try his best to reduce the loss and achieve the maximal level of functional equivalence.

\section{REFERENCES}

[1] Duan Yunli. (2013). Chinese-English Translation for International Business. Tianjing: Nankai University Press.

[2] Eugene, A. Nida. (1964). Toward a Science of Translating. Leiden: E. J. Brill.

[3] Eugene, A. Nida. (1969). Taber C R. The Theory and Practice of Translation. Leiden: E. J. Brill.

[4] Eugene, A. Nida. (1997). The Theory and Practice of Translation. Leiden: E. J. Brill.

[5] Eugene, A. Nida. (1993). Language,Culture and Translation. Shanghai: Shanghai Foreign Language Press.

[6] Eugene, A. Nida. (2001). Language and Culture_Contexts in Translating. Shang Hai: Shang Hai Foreign Education Press.

[7] Halliday, M. A. K. (1997). An Introduction to Functional Grammar. London: Edward Arnold Limited.

[8] Munday, Jeremy. (2000). Introducing Translation Studies: Theories and Applications. London and New work: Routledge.

[9] Newmark, P. (1988). A Textbook of Translation. London: Prentice-Hall.

[10] Reiss, Vermeer. (1984). Basics of General Translation Theories. Germany: Heidelberg University.

[11] Wen Jingjing. (2014). Business Englush Writing and Translation Theory and Practice.Beijing: China WaterPower Press.

[12] Zhaoyong. (2013). A guide to western translation theory. Beijing: Beijing Normal University Press.

Lifen Gao was born in Wuhan, China in 1979. She received her Master's degree in Huazhong University of Science and Technology, China in 2007.

She is currently a lecturer in the Schoool of Foreign Languages, Yangtze University, Jingzhou, China. Her research interests include translation, English teaching and cross-cultural conmmunication.

Ms. Gao has won several awards in teaching competitions and published papers in journals both at home and abroad. 